\title{
Failure analysis of radial bearings used in the refining of petroleum products
}

\author{
Mark Kovalev $^{1 *}$, Daniil Lyashenko ${ }^{1}$, Maksim Kurakin ${ }^{l}$ and Aleksey Shakhmatov ${ }^{1}$ \\ ${ }^{1}$ Peter the Great St. Petersburg Polytechnic University, 195251 Saint Petersburg, Russia
}

\begin{abstract}
The problem of premature failure of bearings is a common type of failure. In most cases, the destruction occurs due to violation of operating conditions. Since the destruction of bearings is a frequent occurrence, consideration of this special case of destruction in the future will help to avoid such problems. The object of research is the screw compressor bearings destroyed during operation. To identify the causes, a collapsed bearing was examined and a bearing that did not collapse during operation.
\end{abstract}

\section{Introduction}

Failure analysis of machine components and structures is an important in any field. Failure of equipment leads at best to economic losses and downtime, and at worst to injuries. In the field of oil and gas, destruction can occur at different stages of the preparation of oil products and their derivatives. The article provides an analysis of the causes of the destruction of the bearing used as part of the compressor unit at one of the enterprises for the preparation of technical lubricants. This case is interesting from the point of view of the analysis of the exploiter's approach and the subsequent analysis of the causes of destruction in the research laboratory, as well as destruction example of the bearing assembly.

\section{Failure analysis}

Repeated destruction of roller radial bearings with cylindrical rollers was occurred during operation. All collapsed bearings were in operation from one month to two, after which their failure occurred. The destruction began with a bearing cage with its subsequent deformation and an obstacle to the normal operation of the installation. During the study, an analysis was carried out of the destroyed bearing and the bearing that was in use without failure (Fig.1).

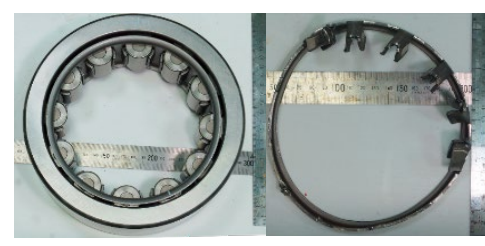

a)

b)

Fig. 1. The investigated elements of the bearing (a) the bearing after operation (b) the destroyed cage
The separator that collapsed during operation was deformed. Its upper and lower rings are separated, the vertical elements are bent or completely separated from the base. Table 1 shows the damage found on the bearing elements. Figure 2 shows the investigated zones of the separator

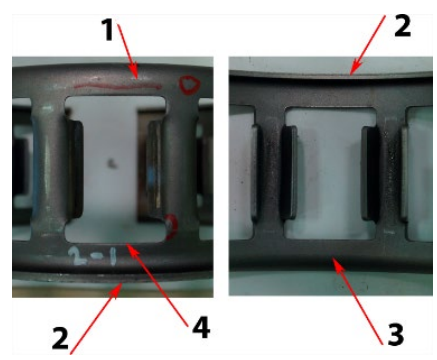

Fig. 2. The investigated zone of the separator; 1-outer surface of the separator; 2 - Separator faces; 3 - the inner surface of the separator; 4 - friction zone of the rollers

Table 1. Inspection results of bearing elements

\begin{tabular}{|c|c|c|}
\hline $\begin{array}{c}\text { Researched } \\
\text { element }\end{array}$ & $\begin{array}{c}\text { Investigated } \\
\text { region }\end{array}$ & Damage view \\
\hline \multirow{4}{*}{$\begin{array}{l}\text { Collapsed } \\
\text { bearing/ } \\
\text { Destroyed } \\
\text { separator }\end{array}$} & Outer surface & $\begin{array}{c}\text { Chips, scratches, traces } \\
\text { of friction. No } \\
\text { corrosion damage }\end{array}$ \\
\hline & Inner surface & $\begin{array}{l}\text { Matte surface without } \\
\text { chips and traces of } \\
\text { friction. Metal } \\
\text { shavings. No corrosion } \\
\text { damage } \\
\end{array}$ \\
\hline & Facets & $\begin{array}{c}\text { Traces of friction, } \\
\text { chips. No corrosion } \\
\text { damage }\end{array}$ \\
\hline & $\begin{array}{c}\text { Roller } \\
\text { Friction } \\
\text { Locations }\end{array}$ & Uneven wear \\
\hline
\end{tabular}

\footnotetext{
* Corresponding author: kovalev.ma@edu.spbstu.ru
} 


\begin{tabular}{|c|c|c|}
\hline \multirow{4}{*}{$\begin{array}{l}\text { Bearing without } \\
\text { failure/ Separator }\end{array}$} & $\begin{array}{l}\text { Outer } \\
\text { surface }\end{array}$ & $\begin{array}{c}\text { Chips, scratches, traces } \\
\text { of friction. No } \\
\text { corrosion damage }\end{array}$ \\
\hline & $\begin{array}{l}\text { Inner } \\
\text { surface }\end{array}$ & $\begin{array}{l}\text { Matte surface without } \\
\text { chips and traces of } \\
\text { friction. Metal } \\
\text { shavings. No corrosion } \\
\text { damage }\end{array}$ \\
\hline & Facets & $\begin{array}{c}\text { Traces of friction, } \\
\text { chips. No corrosion } \\
\text { damage }\end{array}$ \\
\hline & $\begin{array}{c}\text { Roller } \\
\text { Friction } \\
\text { Locations } \\
\end{array}$ & Uneven wear \\
\hline $\begin{array}{c}\text { Bearing without } \\
\text { failure /Outer } \\
\text { ring }\end{array}$ & $\begin{array}{l}\text { Rolling } \\
\text { zone }\end{array}$ & $\begin{array}{l}\text { Dents, sinks, vertical } \\
\text { and horizontal } \\
\text { scratches }\end{array}$ \\
\hline $\begin{array}{l}\text { Bearing without } \\
\text { failure/Rollers }\end{array}$ & $\begin{array}{l}\text { Friction } \\
\text { surface }\end{array}$ & $\begin{array}{l}\text { Spalling, uneven wear, } \\
\text { vertical scratches }\end{array}$ \\
\hline
\end{tabular}

During the initial on-site inspection, a theory of failure due to pitting corrosion was put forward. Such conclusions were made as gas (ammonia) containing moisture was used during operation.

In general terms, pitting corrosion is local corrosion on a metal surface in places where the common metal surface is relatively not damaged by corrosion and is often coated with passivating films or scale [1]. Pitting corrosion of carbon steels is accompanied by the formation of corrosion products, which usually form over ulcers [2]. To detect corrosion damage to the elements of the destroyed separator, a visual inspection was carried out and metallographic sections were prepared.

Electrolyte is necessary for corrosion processes. The oil, which is used as a lubricant, was analyzed. The analysis showed the presence of water (up to 0.007, mass $\%$ ) and alkalis in the oil, $\mathrm{pH}$ ranged from 9.9 to 10.4 . Such an environment is favorable for carbon steels (of which the bearing elements are made), since in an alkaline medium the surface is passivated according to the Purbe diagram.

A visual inspection of parts of the destroyed separator showed no corrosion damage or corrosion products. There are metal shavings on the inner wall (Fig. 3).

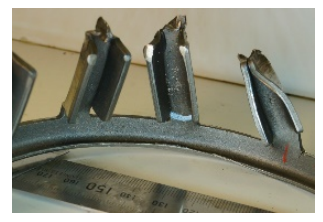

Fig. 3. Metal chips on the inner wall of the separator

On the separator there were recesses on the separator caused by mechanical stress (Fig. 4). Damage was absent on the inner surface of the separator.

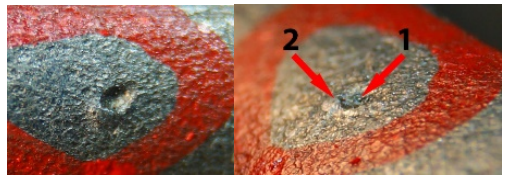

Fig. 4. Mechanical damage on the outer surface of the separator
Macrophotos of the same damage, taken with a change in the shooting angle, allow you to see the metal displaced from the recess (2) in case of damage (1). On the outer wall of the destroyed separator there are a lot of chips, scuffs, scratches and other mechanical defects. There were no defects on the inner wall of the same segment, and the surface retained a matte color. Figure 5 shows a similar comparison of the surfaces of a destroyed separator.

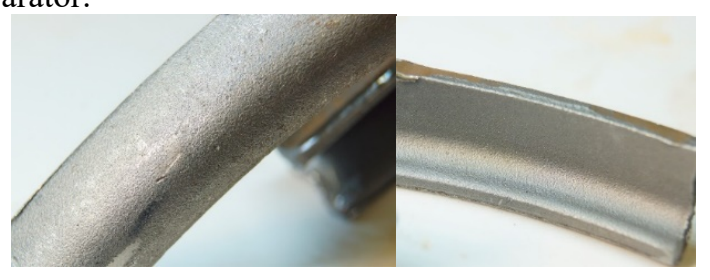

a)

b)

Fig. 5. Macro photographs of the surfaces of the separator (a) the outer surface (b) the inner surface

For metallographic evaluation, thin sections were cut out from the broken segments of the separator. Figure 6 shows the cutting zones of the samples.

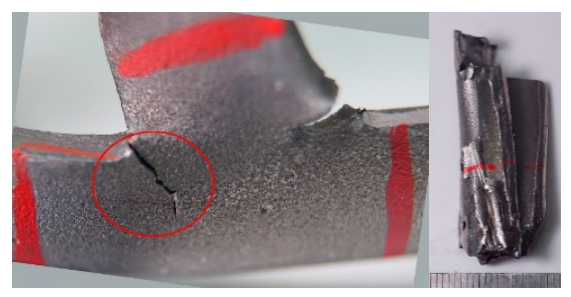

a)

b)

Fig. 6. Production areas of metallographic sections

The metallographic analysis showed no signs of corrosion, and there are no corrosion products in the recesses (Fig. 7).
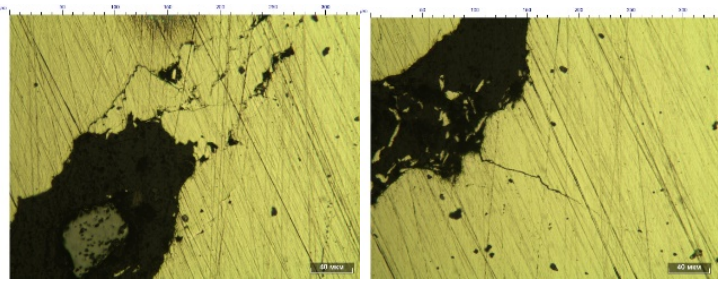

Fig. 7. Cracks of the destroyed separator

Multiple cracks indicate high fracture energy. After operation, there is also no corrosion damage on the surface of the entire bearing. No traces of pitting were found on the outer ring, rollers and separator. The surface is either matte as in the case of the cage, or glossy in the case of the rollers and the outer bearing ring. An oil film is present on the friction surfaces and the separator.

The main causes of bearing failure are mechanical stress [3]. Factors such as overload, misalignment, installation defects, insufficient amount of lubricant can lead to excessive mechanical stress on the bearing assembly and its subsequent destruction. Since both a collapsed separator and a whole separator after operation 
were provided for research, a comparison and search for similar mechanical damage was carried out.

Inspection of the destroyed separator revealed multiple wear zones. Zones in the places of friction of the rollers and the inner walls of the separator were also studied. Figure 8 shows signs of wear during operation of the bearing. The burrs formed due to friction during operation show an uneven load distribution on the bearing roller.

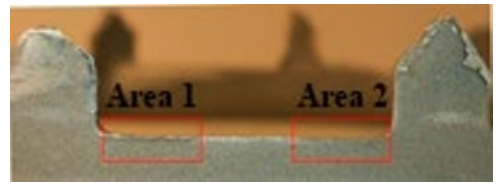

Fig. 8. Areas of uneven wear from roller friction

The friction load in area one was greater than in area two, as evidenced by the resulting burrs. There are also zones on the separator ring with uniform wear of the places of friction of the rollers. Figure 9 shows an example of uniform wear.

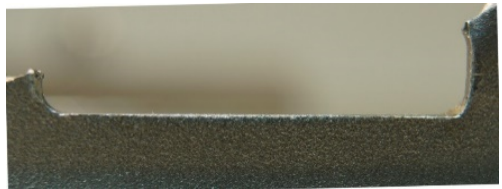

Fig. 9. The area of uniform wear from the friction of the roller

The destruction of the separator usually occurs due to misalignment of the bearing during installation, excess load, vibration, torn operating modes (sudden acceleration and decrease in rotation speed), lubricant and temperature[4]. To search for patterns in the wear of the cage and the separation of the primary damage from those that arose during the re-starts, the cage from the previously used bearing was studied

The cage from the bearing was removed by cutting a segment on a band saw. To identify patterns of wear, similar zones were studied, as in the destroyed separator. The surface of the separator wall also has traces of friction. In figure 10 , the bottomhole is noticeable. The wear on the cage from the whole bearing is similar to the wear observed on the destroyed cage.

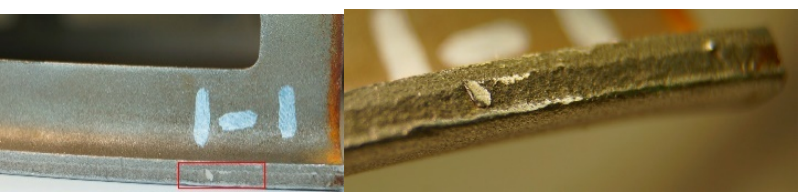

Fig. 10. Damage to the surface of the separator

On the outer faces there are also chips and bottom holes (Fig. 11).

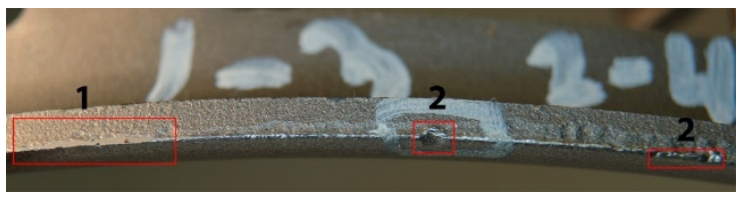

Fig. 11. Chips on the verge of the separator

Moreover, on the inner surfaces of the separator facing the shaft, no damage.

During visual inspection of the bearing rollers after operation, uneven wear paths were found on the surface. All 12 rollers have a wear strip with traces of metal chipping. Figure 12 shows the detected damage. on the example of one roller.
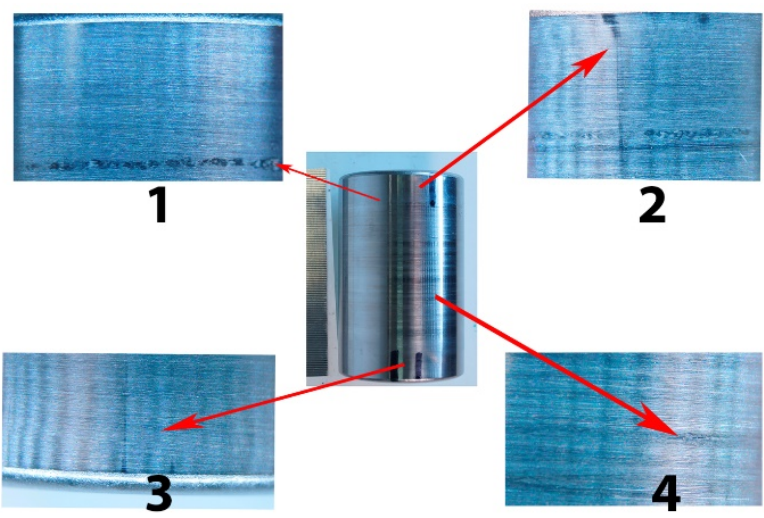

Fig. 12. Damage detected on the surface of the roller

Zone 1 - a friction track in the upper part of the roller with traces of metal spalling. There is no such wear on the bottom of the roller. Zones 2 and 3 are vertical risks that could arise both during the installation of the bearing and during its dismantling from the installation. The risks at the top and bottom of the roller are in the same plane. In zone 4, metal chipping is presented on the surface of the roller. In addition to the friction track in the upper part, single spallings are present along the body of the roller. Figure 13 shows a similar track on another roller.

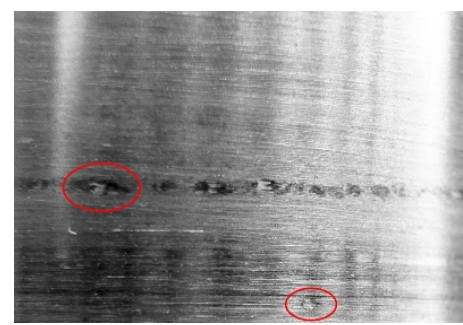

Fig. 13. Chipping on the surface of the roller

Damage in the form of spalling can occur due to foreign particles (debris) in the friction zones, improper installation of the bearing, exceeding rated loads, increased vibration or poor-quality lubricant. Dents and spalls on raceways were found on the outer ring (Fig. 14).

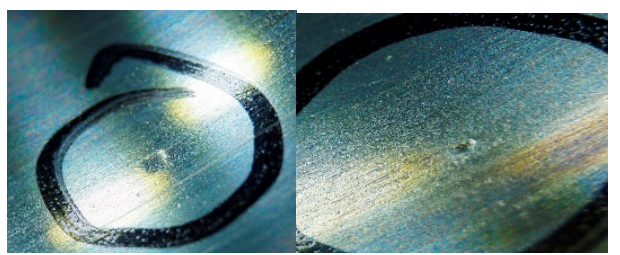

Fig. 14. Dents and chipping on the racetrack of the outer ring of the bearing 
Dents and spalls are random in nature. Indentations occur on rolling surfaces and bodies and are formed due to debris (metal particles) entering the friction spaces

\section{Conclusions}

As a result of the study of the destroyed cage and the elements of the whole bearing after operation, mechanical damage was discovered. No traces of corrosion processes were found.

The most likely cause of the destruction of the bearing is the ingress of mechanical particles (chips) on both the rolling elements and on the compressor rotor. Metal chips can lead to short-term jamming of bodies of revolution and rolling, having a small gap. Jams lead to an increase in the load on the compressor components, in particular the bearings, with the possibility of further destruction. This conclusion is confirmed by numerous traces of uneven wear of both the rollers and the outer race of the bearing, the presence of scoring on the rotors of the compressor unit and the presence of metal chips in the oil and on the bearing elements.

Metal shavings may result from the use of ammonia containing water. The presence of water leads to corrosion damage to carbon steel pipelines through which ammonia circulates. As a result of this, corrosion products are formed, which can act as mechanical impurities that fall on the bodies of rotation and rolling.

\section{References}

1. E. Heidersbach, Metallurgy and Corrosion in Oil and Gas Production, 296, (2011)

2. I. Rosenfeld, Corrosion and metal protection, 448, (1969)

3. Machinery Failre Analysis Handbook $1^{\text {st }}$ Edition, 308, (2006)

4. Failure Analysis Case Studies $1^{\text {st }}$ Edition, 456, (2001) 